\title{
Two Cases of the Nephrotic Syndrome Associated with the Unilateral Renal Vein Thrombosis
}

\author{
Takeo Kuroyanagi, M D, Shigeaki Nagashima, M D, \\ Kazuo Kura, M D, Kifumi Fujitani, M D, \\ and Hirobumi Nagoya, M D
}

\begin{abstract}
The unilateral renal vein thrombosis is of ten associated with the nephrotic syndrome demonstrating histologic findings similar to the membraneous or membrano-proliferative glomerulonephritis. Most studies have suggested that the renal vein thrombosis may be a complication of the nephrotic syndrome, which has been induced by its hypercoagulable state rather than its cause. However, others suppose that the unilateral renal vein thrombosis is an initial event and the membraneous glomerulonephritis is due to the immunologic injuries of glomeruli induced by the renal vein thrombosis. Two cases of the nephrotic syndrome associated with the unilateral renal vein thrombosis have been reported. Case 1 was a 48 year old female. She had the Sjögren's syndrome. She had the left renal vein thrombosis associated with the nephrotic syndrome but no hypercoagulable state. The immunofluorescent studies on kidey biopsy specimens demonstrated the presence of the immune complex nephritis. Case 2 was a 31 year old male. He had the nephrotic syndrome associated with the left renal vein thrombosis and the myocardial infarction. He had a hypercoagulable state. Histological examinations of kidney biopsy specimens revealed the minimal change lesions and no depositions of $\operatorname{IgG}$ and $\beta_{1} \mathrm{C}$ were demonstrated by immunofluorescence.
\end{abstract}

Key Words: Unilateral renal vein thrombosis, Membraneous glemerulonephritis, Nephrotic syndrome, Immune complex nephritis, Hypercoagulable state.

Most patients with the renal vein thrombosis were not diagnosed antemortem $^{1,2)}$ before 1956. However, the number of reports of living patients with this disorder who had been diagnosed antemortem ${ }^{3-6)}$ have been increasing in the past the few years after the development of the more advanced radiological technique and the selective catheterization. ${ }^{7-8)}$

The renal vein thrombosis is often associated with the nephrotic syndrome ${ }^{3-6)}$ and the renal histologic findings are similar to these of the membraneous glomerulonephritis or the membranoproliferative glomerulonephritis ${ }^{3-6,9-12)}$ in many cases.
Most studies have suggested that glomerular lesions precede the renal vein thrombosis and the renal vein thrombosis might be a complication ${ }^{4-6,13-15)}$ of the nephrotic syndrome rather that its cause. An increased incidence of thromboembolic phenomena in patients with the nephrotic syndrome had been observed and attributed to a hypercoagulable state. ${ }^{16)}$ Although the renal vein thrombosis has been unilateral, bilateral glomerular lesions demonstrating positive immunofluorescence for $\operatorname{IgG}$ have been reported. ${ }^{6,14,15,17)}$ These immunologic findings have led to the speculation ${ }^{17)}$ that the renal vein thrombosis is the first event

From the First Department of Internal Medicine, Saitama Medical School, Saitama.

Received for publication October 20, 1977.

Reprint request to: Takeo Kuroyanagi, The First Department of Internal Medicine, Saitama Medical School, Moroyama-machi, Saitama-ken, Pref, 350-04, Japan. 
and the nephrotic syndrome is due to immunologic lesions of glomeruli induced by the renal vein thrombosis.

The purpose of this report is to report two cases of unilateral renal vein thrombosis associated with nephrotic syndrome and to comment the relathionship between the unilateral renal vein thrombosis and the nephrotic syndrome.

\section{CASE REPORT}

Case 1.

A 48-year-old woman was admitted to Saitama Medical School Hospital because of massive proteinuria, edema, hypoproteinemia and arthritis.

There was nothing particualr in her familial and past history. She had the rheumatoid arthritis and had repeated remissions and exacerbations in spite of the treatment during past 10 years. During these periods she had no proteinuria on the repeated urinalysis. She had an episode of flank pain accompanied with nausea and vomiting at the beginning of November, 1975. Two months later she complained the fatigue, the edema of face and swollen ankles. She consulted her physician and was found to have venous dilatations on the abdominal wall and a massive proteinuria. She was admitted to Fukaya Red Cross Hospital because of edema and proteinuria. Evaluations revealed the ascites, a marked proteinuria and the hypercholesterolemia. The diagnosis of nephrotic syndrome was made and she was treated with $40 \mathrm{mg}$ of prednisolone daily for two months. The edema and ascites disappeared and the proteinuria reduced markedly by the treatment. However, she began to complain the dry mouth and dry eyes. Since the marked hypoproteinemia persisted in spite of the treatment, she was suspected to have the protein losing gastroenteropathy and admitted to Saitama Medical School Hospital for evaluations.

On admission she had a pale face and no ascites. She could not walk because of deformities of bilateral knee and ankle joints. The pulse rate was 76 per minute and the temperature $36.7^{\circ} \mathrm{C}$. Blood pressure was $106 / 60 \mathrm{mmHg}$. There were neither skin pigmentations nor depigmentations. The skin was dry, but there were no physical findings of the scleroderma. Salivary and lacriminal secretions were slightly reduced. There were the swan neck and boutonian deformities of bilateral fingers, hallux valgus and claw toes. Physical examinations of the chest revealed nothing particular. There were marked venous dilatations showing an upward blood flow on the abdominal wall and the lumbal area, suggesting the presence of an incomplete occlusion in vena cava inferior. The liver was palpable $2 \mathrm{~cm}$ below the right costal margin. The spleen and the kidney were not palpable. No abnormal abdominal mass was found. A remarkable atrophy of musculature of bilateral forearms and legs was demonstrated. There were no abnormal neurological findings.

Repeated urinalysis revealed the daily urinary protein excretion ranging 10 to $15 \mathrm{~g}$ per day. No abnormal findings were demonstrated on urinary sediments. $\mathrm{Hb}$ was $8.4 \mathrm{~g} / \mathrm{dl}, \mathrm{RBC} 280 \times 10^{4}$ per $\mathrm{cmm}$, Ht $24 \%$, WBC 8300 per cmm, platelets $20 \times 10^{4}$ per $\mathrm{cmm}$ and reticulocytes $3.4 \%$. Haemogram was within normal limits. Bleeding time was 4 minutes 30 seconds, whole blood coagulation time $9 \mathrm{~min}, \mathrm{PT} 14 \mathrm{sec}(94 \%)$, PTT $55 \mathrm{sec}(88 \%)$, and thrombotest $100 \%$. Fibrinogen was $148 \mathrm{mg} / \mathrm{dl}$ and serum FDP $7 \mu \mathrm{g} / \mathrm{ml}$. Thrombelastogram revealed $\mathrm{r}=10$ $\min , \mathrm{k}=3 \mathrm{~min}, \mathrm{ma}=40 \mathrm{~mm}$ and $\mathrm{Me} 98 \%$. Serum total protein was $3.7 \mathrm{~g} / \mathrm{dl}$ (albumin $26.8 \%, \alpha_{1}$-globulin $6.3 \%, \alpha_{2}$-globulin $37.5 \%$, $\beta$-globulin $8.6 \%, \gamma$-globulin $20.5 \%, \mathrm{~A} / \mathrm{G} 0.4$ ). IgG was $700 \mathrm{mg} / \mathrm{dl}$, IgA $331 \mathrm{mg} / \mathrm{dl}, \quad I g M$ $301 \mathrm{mg} / \mathrm{dl}, \operatorname{IgD} 4 \mathrm{mg} / \mathrm{dl}$ and $\operatorname{IgE} 368 \mathrm{IU} / \mathrm{ml}$. Serum total cholesterol was $392 \mathrm{mg} / \mathrm{dl}$. Serum electrolytes were $\mathrm{Na} 140 \mathrm{mEq} / \mathrm{l}, \mathrm{K}$ $5.1 \mathrm{mEq} / 1$, Ca $7.6 \mathrm{mg} / \mathrm{dl}, \quad$ P $3 \mathrm{mg} / \mathrm{dl}, \quad \mathrm{Mg}$ $2.7 \mathrm{mg} / \mathrm{dl}$.

Liver function tests were within normal limits. The PSP test (15 min) was $22 \%$, serum creatinine $0.6 \mathrm{mg} / \mathrm{dl}, \mathrm{BUN} 15 \mathrm{mg} / \mathrm{dl}$, creatinine clearance $42.3 \mathrm{ml} / \mathrm{min}$.

Serological tests were RA test H, ANF 


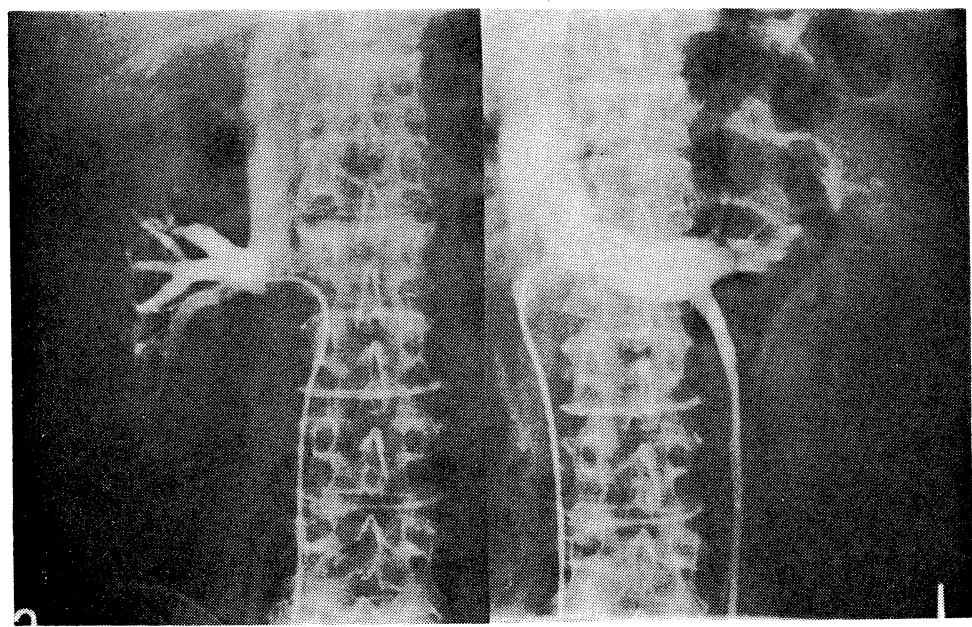

Fig. 1. Right renal venogram showed no abnormalities. Left renal venogram demonstrated renal vein occulsions in main intrarenal vein.

titer $20 \times$, anti-DNA titer $320 \times$, anti-thyroglobulin titer $25,400 \times$, anti-microsome titer $6,400 \times$, anti-renal tubular microsome titer $6,400 \times, \quad \mathrm{CH}_{50} 30 \mathrm{U} / \mathrm{ml}, \quad \beta_{1} \mathrm{C} / \beta_{1} \mathrm{~A}$ globulin $90 \mathrm{mg} / \mathrm{dl}, \mathrm{C} 3$ activator $20 \mathrm{mg} / \mathrm{dl}, \beta_{1} \mathrm{E}$ globulin $55 \mathrm{mg} / \mathrm{dl}$.

Examinations by RISA and ${ }^{131}$ I-PVP demonstrated the absence of the protein losing gastroenteropathy.

EGG and chest X-Ray films were within normal limits. The X-Ray examination of joints revealed abnormal findings consistent with the changes in the stage IV rheumatoid arthritis. The sialography revealed irregular narrowings and dilatations of salivary ducts with the apple tree patterns. Shirmer's test was negative. Biopsy specimens of parotid gland demonstrated fibrosis, hyalinoid swelling of arterioles and infiltrations of lymphocytes and plasma cells. The diagnosis of the Sjögren's syndrome was made. The selective renal venogram demonstrated an occulsion in the trunk of left renal hilus and filling defect of left intrarenal veins (Fig. 1). Inferior vena cavagram revealed the presence of incomplete obstructions (Fig. 2).

A right kidney biopsy specimens were obtained from the kidney without an evidence of the renal vein thrombosis. Sections of biopsy specimena were examined his-

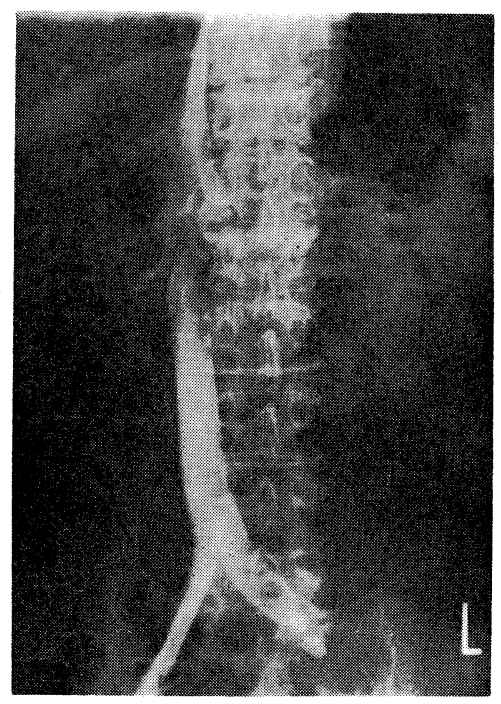

Fig. 2. Inferior vena cavagram demonstrating the presence of incomplete occulsion.

tologically and immunohistologically by means of immunofluoresence.

In renal biopsy specimens all the glomeruli showed the diffuse basement membrane thickening of a moderate degree. There was a moderate hypercellularity due to proliferation of mesangium and prominence of swollen epithelial cells.

The immunofluorescence microscopic examinations revealed the coarse granular 
deposition of $\operatorname{IgG}$ and $\beta_{1} \mathrm{C}$ globulins along the glomerular basement membrane. The mesangial areas were negative for the deposition of $\operatorname{IgG}$ and $\beta_{1} \mathrm{C}$ globulins (Fig. 3).

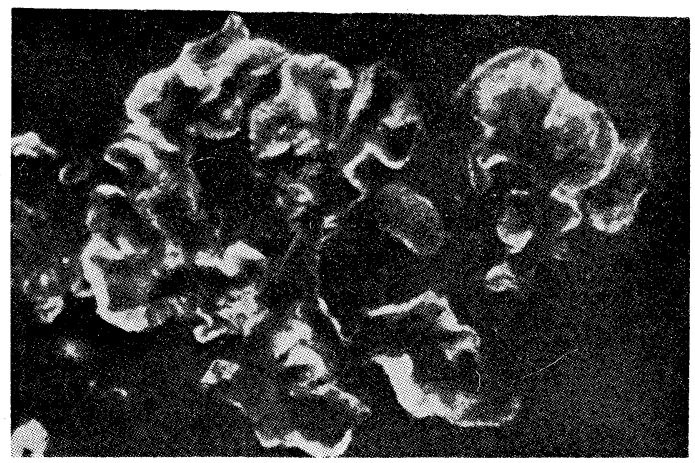

Fig. 3. Fluorescene microscopy revealed corse granular depositions of IgG along glomerular basement membranes.

Immunofluorescence of the kidney biopsy specimen.

On the basis of these findings, the diagnosis of the nephrotic syndrome due to the immune complex nephritis associated with the unilateral renal vein thrombosis was established. The patient was treated with a low salt diet, furosemide and heparin. The edema disappeared and the urinary protein excretion reduced to 1.0 $2.0 \mathrm{~g}$ per day. The serum total protein recovered to $5.4 \mathrm{~g} / \mathrm{dl}$.

\section{Special studies}

Since the bilateral glomerulopathy was considered, the proteinuria of each kidney was measured quantitatively and qualitatively by means of the selective ureteric catheterization. The qualitative determination of urinary protein excretion was carried out by biuret method.

The quantitative determination for albumin, transferrin and $\operatorname{IgG}$ was done for serum and urine by the single radial immune diffusion method. The clearance of these proteins expressed as a percentage of transferrin clearance, was calculated from these date and plotted as a function of molecular weight. The slope or this line was used as a measure of the selectivity. ${ }^{18,19)}$

The anti-thrombin III levels in serum were measured by the single cross immunoelectrophoresis with rabbit antiserum to human antithrombin III (Nyegaadt and Co, A/S Oslo) according to Laurell ${ }^{20)}$ and were expressed as a percentage of amount present in the pooled serum of 30 normal adults.

Results

The quantitative protein excretion was similar for the left $(2.66 \mathrm{mg} / \mathrm{min})$ and right kidney $(3.1 \mathrm{mg} / \mathrm{min}$ ).

The serum anti-thrombin level was $98 \%$ of normal.

The selectivity of the protein excretion of each kidney is shown in Fig. 4. The slope of the two lines is similar. Therefore the clearance of protein with different molecular weight was identical for the left and right kidney respectively (Fig. 4).

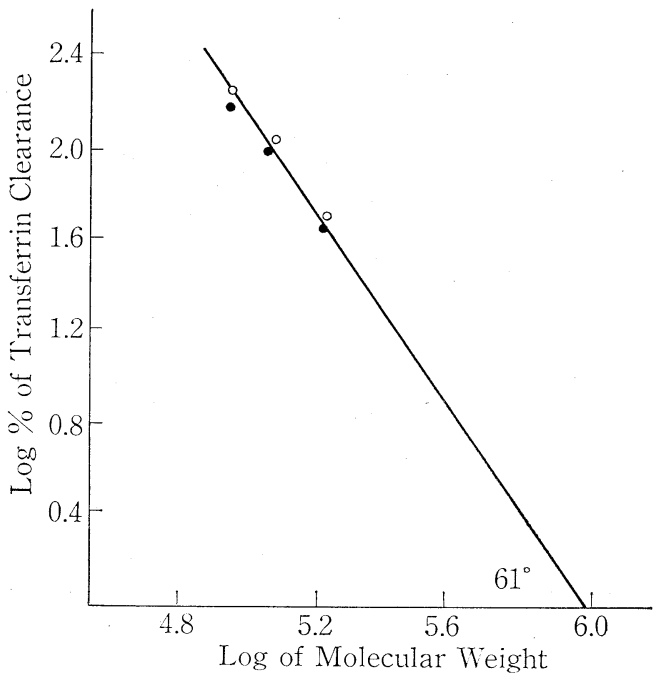

Fig. 4. Selectivity of Urinary excretion of left kidney and right kidney.

Case 2

A 31-year-old man was admitted to Saitama Medical School Hospital because of a severe chest pain attack and dyspnea on May 7, 1972. 
There was nothing particular in his familial and past history. $\mathrm{He}$ was well unitl the end of October, 1971, when he complained the general fatigue and edema. $\mathrm{He}$ consulted his physician and was found to have a marked proteinuria. He was admitted to Ogawa Red Cross Hospital on Feburary 5, 1972 and evaluations revealed that he had the nephrotic syndrome. He was treated with $40 \mathrm{mg}$ of prednisolone daily for 3 months and the edema disappeared without a reduction of urinary protein excretion and an improvement of hypopoteinemia by the treatment. He was discharged on May 3, 1972. On May 5, 1972 he complained a severe chest pain attack continuing for 2 hours at night. In the next morning he again complained the similar severe chest pain accompanied with dyspnea, palpitation and dizziness. He was admitted to Saitama Medical School Hospital on May 7, 1972.

On admission he was dyspnoic but had no cyanosis. A slight edema was present on feet and legs. The pulse rate was 86 per minute and blood pressure $90 / 70 \mathrm{mmHg}$. The chest was resonant and moist rales were audible on posterior inferior chest bilaterally. No heart murmur was audible. There were no abnormal physical findings in abdomen.

The urinary protein excretion averaged $20 \mathrm{~g}$ per day. There were no abnormal findings in urinary sediments. $\mathrm{Hb}$ was 12.5 $\mathrm{g} / \mathrm{dl}, \mathrm{RBC} 403 \times 10^{4}$ per $\mathrm{cmm}$, WBC 13,400 per $\mathrm{cmm}$, platelets $18.2 \times 10^{4}$ per $\mathrm{cmm}$. BSR was $100 \mathrm{~mm}$ per hour and CRP H. CPK was $175 \mathrm{U} / \mathrm{ml}$, GOT $175 \mathrm{U} / \mathrm{ml}$, GPT $58 \mathrm{U} /$ $\mathrm{ml}$, LDH $230 \mathrm{U} / \mathrm{ml}$. Serum total cholesterol was $312 \mathrm{mg} / \mathrm{dl}$, triglyceride $234 \mathrm{mg} / \mathrm{dl}$, creatinine $0.7 \mathrm{mg} / \mathrm{dl}, \quad \mathrm{BUN} 20 \mathrm{mg} / \mathrm{dl}$, Na 137 $\mathrm{mEq} / \mathrm{l}, \mathrm{K} 4.9 \mathrm{mEq} / 1, \mathrm{Cl} 98 \mathrm{mEq} / 1$ and $\mathrm{Ca}$ $8.8 \mathrm{mg} / \mathrm{dl}$.

Serum total protein was $5.2 \mathrm{~g} / \mathrm{dl}$, albumin $35 \%, \alpha_{1}$ globulin 9\%, $\alpha_{2}$ globulin $28 \%, \beta$ globulin $12 \%, \gamma$ globulin $16 \%$ and $\mathrm{A} / \mathrm{G} 0.7$. IgG was $658 \mathrm{mg} / \mathrm{dl}, \operatorname{IgA} 171 \mathrm{mg} / \mathrm{dl}$ and IgM $771 \mathrm{mg} / \mathrm{dl}$. Serum total lipid $1,151 \mathrm{mg} / \mathrm{dl}$, phospholipids $376 \mathrm{mg} / \mathrm{dl}$, NEFA $640 \mathrm{Eq} / 1$. Bleeding time was 2 minutes. The whole blood clotting time was markedly shortened, being 4 minutes. The thrombelastogram revealed $\mathrm{r}: 5 \mathrm{~min}, \mathrm{k}: 2 \mathrm{~min}$, and $\mathrm{ma}: 60 \mathrm{~mm}$. PT was 11.5 sec., PTT $130 \%$, Factor VIII $135 \%$, fibrinogen $640 \mathrm{mg} / \mathrm{dl}$, anti-thrombin III levels of serum (Laurell's method) 50\% of normal values, indicating that the patients had a hypercoagulable state.

Chest X-Ray films showed no abnormalities. ECG demonstrated the presence of anteroseptal myocardial infarction, as shown in Fig. 5. He was put in the oxygen tent and treated with dipyridamol, digitoxin, furosemide and heparin. After the recovery from myocardial infarction intravenous pyelography was carried out. IVP demonstrated a slight difference in the size of the left $(14 \times 6 \mathrm{~cm})$ and right kidney $(12$ $\times 5 \mathrm{~cm})$. The renal vein thrombosis was suspected and the selective renal venography was carried out. Inferior vena cavagram was within normal limits. Selec-

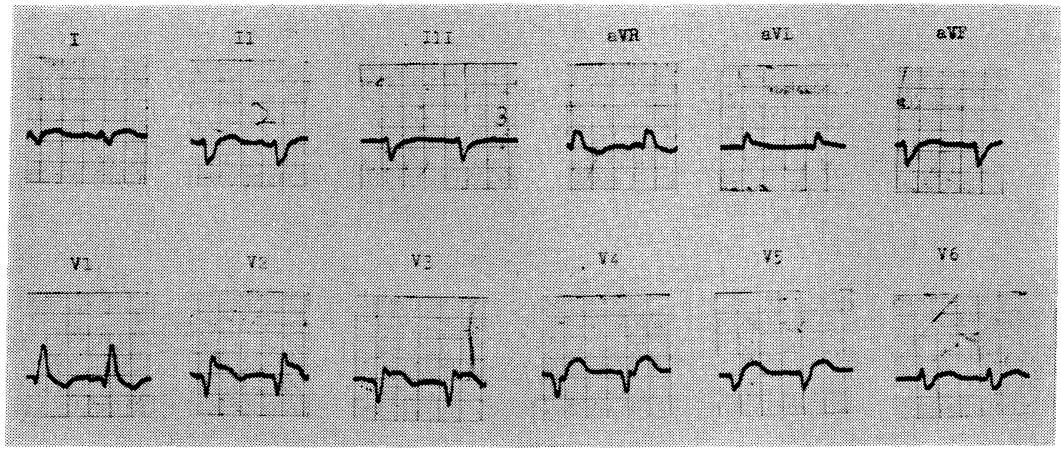

Fig. 5. ECG showing anteroseptal myocardial infarction. 
tive right renal venogram showed no evidence of thrombi in visualized renal venous trunk and major branches. The left renal venogram revealed a large sharply marginated ovoid filling defect in the main trunk at the renal hilus (Fig. 6). Selective ureteric catheterization demonstrated that quantitatrive urinary protein excretion was similar for the left $(8.05 \mathrm{mg} / \mathrm{min})$ and right kidney $(7.96 \mathrm{mg} / \mathrm{min})$.

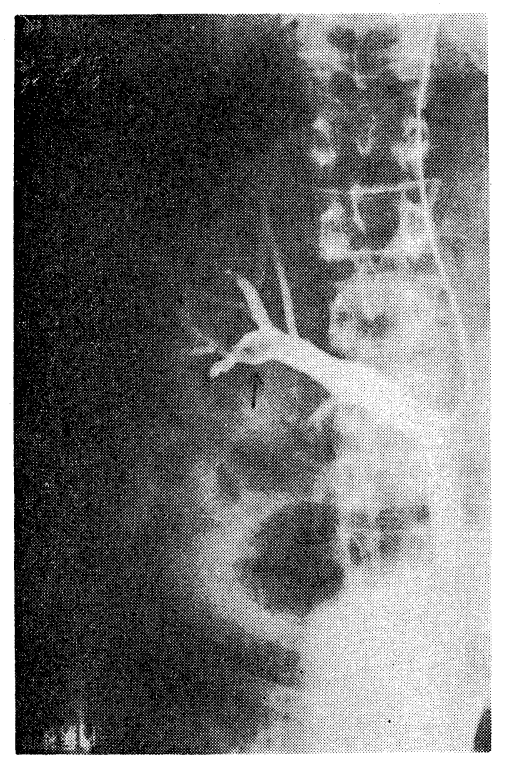

Fig. 6. Selective left renal venogram demonstrating the presence of an ovoid filling defect in main trunk at the renal hilus.

Histopathologic findings of renal biopsy specimens.

Glomeruli demonstrated a mild diffuse increase in mesangial cell and mesangium with no nodular hyaline deposits. The basement membrane were generally smooth and without evidence of diffuse thickening (Fig. 7).

There was no evidence of $\operatorname{IgG}, \operatorname{IgA}$, $\operatorname{IgM}$ or $\beta_{1} \mathrm{C}$ depositions within glomeruli by the indirect immunofluorescence.

The heparin treatment was begun. However, the heparin treatment resulted in a transient reduction of urinary protein excretion but in no persistent improvement of nephrotic syndrome.

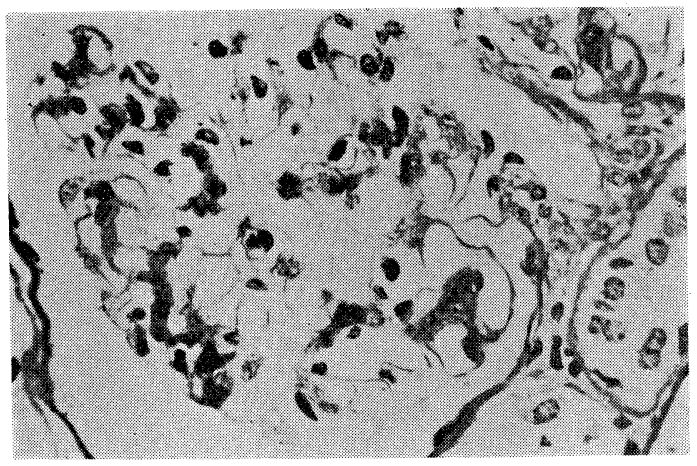

Fig. 4. Glomeruli demonstrated a mild diffuse increase in mesangial cells and mesangium with no nodular hyaline deposits. The basement membrane were generally smooth and without evidence of diffuse thickening.

There was no evidence of $\operatorname{IgG}, \operatorname{IgA}, \operatorname{IgM}$ or $\beta_{1} \mathrm{c}$ depositions within glomeruli by indirect immunofluorescence.

Histopathologic findings of renal biopsy specimens of Case 2.

\section{COMMENT}

There have been an increasing number of reports ${ }^{6,14,15,17)}$ that the presence of a bilateral membraneous glomerulonephritis has been confirmed in the unilateral renal vein thrombosis. The presence of a bilateral glomerular lesions was confirmed by the renal biopsy and selective ureteric catheterization in our present two cases of the unilateral renal vein thrombosis associated with nephrotic syndrome.

From literatures, it has usually been assumed that most patients with the renal vein thrombosis have some characteristic $^{2,15,21)}$ symptoms, such as flank pain and hematuria. However, Rosemann ${ }^{3)}$ has reported that the incidence of such clinical symptoms and signs is not as frequent as previously suggested.

The first patient had no abnormal findings in urinalysis before the flank pain attack had occurred. Several weeks later she was found to have the venous dilatation on the abdominal wall and the lumbar area. So it seems likely that she developed the renal vein thrombosis at the time when she had a flank pain attack. 
The second case had no characteristic symptoms suggesting the development of the renal vein thrombosis. He had had the nephrotic syndrome several months before the myocardial infarction occurred. The selective renal venogram revealed the enlargment of left kidney with left renal vein thrombosis. Wegner ${ }^{22}$ has repoted that in an acute renal vein occulsion the enlargment of the kidney reaches its maximum at one week and that the size returns to normal within 2 months. Therefore, patient's large left kidney suggests that the renal vein thrombosis has occurred at the same time when he developed myocardial infarction.

Some authors believe that the membraneous glomerulonephritis is a primary event $^{4-6,13-15,23,24)}$ and the renal vein thrombosis is secondary and not contributable to the proteinuria.

McCarthy $^{13)}$ and Jackson ${ }^{25)}$ have reported that a low incidence of proteinuria was found in cases of the renal vein thrombosis with or without the inferior vena caval vein thrombosis (two of 17 and three of 24 , respectively). Therefore, they believe that the unilateral renal vein thrombosis per se is unlikely to be a direct cause of proteinuria.

A high incidence of thromboembolic phenomena has been reported in patients with the nephrotic syndrome. It is explained that a state of hypercoagulability associated with the nephrotic syndrome leads to the thrombosis. Several possible mechanism had been suggested to explain a hypercoagulable state in the nephrotic syndrome such as an increase in platelets and plasma procoagulats ${ }^{16,27,28)}$ and a reduction of antithrombin III. The reduction of antithrombin $\mathrm{III}^{30}$ ) of less than $50 \%$ of normal have a reported incidence of the systemic thrombosis in 70\% of cases.

It is well established that patients with the nephrotic syndrome associated with the renal vein thrombosis which is the consequence of the hypercogulable state associated with the nephrotic syndrome, ${ }^{16,27,28)}$ show the low level of antithrombin III. ${ }^{24,29)}$
Therefore, the low level of antithrombin III in serum seems likely to be responsible for an increased incidence of venous thrombosis in patients with nephrotic syndrome.

Moore $^{17)}$ suggested that the unilateral renal vein thrombosis results in the renal tissue injuries with the renal antigens release and the subsequent production of anti-renal tissue antibodies leading to an immune complex lesions of glomeruli, by the similar mechanism of experimental autoimmune $^{31,32)}$ nephritis. He considers that the renal vein thrombosis is the initial event and the membraneous glomerulonephritis and the nephrotic syndrome are subsequent phenomena.

Harris $^{33)}$ demonstrated the gamma globulin deposition in the glomerular basement membrane of the contralatelal kidney after an experimental unilateral constriction of the renal vein.

In the first case, the absence of proteinuria before the occurrence of renal vein thrombosis, the absence of a state of hypercoagulability, the normal levels of serum anti-thrombin III and the deposition of gammaglobulins and $\beta_{1} \mathrm{C}$ globulins within glomeruli favor for the Moore's concept. In the second case, the concomitant development of the myocardial infarction and the renal vein thrombosis, the presence of a hypercoagulable state, the decrease of serum anti-thrombin III and the absence of depositions of gammaglobulins and $\beta_{1} \mathrm{C}$ globulins within glomeruli are favorable for the concept that nephrotic syndrome is a primary event and renal vein thrombosis is secondary.

However, the exact etiologic relationship between the unilateral renal vein thrombosis and the nephrotic syndrome remains still to be clarified in these two cases.

\section{REFERENCES}

1) Helper $\mathrm{AB}$ : Thrombosis of renal veins. $J$ Urol 31 : 527, 1934.

2) Harrison GV, Milne MD, Steiner RE: Clinical aspects of renal vein thrombosis. 
Q J Med 25: 285, 1956.

3) Rosemann E, Pollak VE, Pirani CL: Renal vein thrombosis in the adult: a clinical and pathologic study based on renal biopsies. Medicine 47: 269, 1968.

4) Balabanian MB, Schnetzler DE, Kalouantides GJ: Nephrotic syndrome, renal vein thrombosis and renal failure. Am J Med 56: 768, 1973.

5) Duffy JI, Letteri J, Cinque $\mathrm{T}$, et al : Renal vein thrombosis and nephrotic syndrome. Am J Med 56 : 663, 1973.

6) Schwatz MM, Lewis EJ: Immunopathology of the nephrotic syndrome associated with renal vein thrombosis. Am J Med 54:528, 1972.

7) Peart WS, Sutlon D: Renal vein catheterization and venography: a new technique. Lancet 2: 817, 1958.

8) March TL, Halpern M: Renal vein thrombosis demonstrated by selective renal phlebography. Radiology 81 : 958, 1963.

9) Chon LH, Lee J, Hopper J, Najarian SS : The treatment of bilateral renal vein thrombosis and nephrotic syndrome. Surgery 64 : 387, 1968.

10) Panner B: Nephrotic syndrome in renal vein thrombosis. Arch Path 76: 303, 1963.

11) Lindenbaum J, Scheidt SS: Chylous ascites and the nephrotic syndrome: Report of a case associated with renal vein thrombosis. Am J Med 44 : 830, 1968.

12) Pollak VE, Pirani CL, Seskind C, et al : Bilateral renal vein thrombosis: Clinical and electromicroskopic studies of a case with complete recovery after anticoagulant therapy.

13) McGarthy LI, Titus JL, Daugherty M, et al: Bilateral renal vein thrombosis and the nephrotic syndrome in adults. Ann Int Med 58: 837, 1963.

14) Morris JF, Ginn EH, Tomptson DD: Unilateral renal vein thrombosis associated with the nephrotic syndrome. Am J Med 34: 867, 1963.

15) Llack F, Arieff AI, Massry SG: Renal vein thrombosis and nephrotic syndrome. A prospective study of 36 adult cases. Ann Int Med $83:$ 8, 1975.

16) Kendall AG, Lohmann RC, Doseter TB, et el: Nephrotic syndrome: a hypercoagulable state. Arch Int Med 127: 1021, 1971.

17) Moore HL, Katz R, McIntosh R, et al: Unilateral renal vein thrombosis and the nephrotic syndrome. Pediat. 50: 598, 1972.

18) Blainey JD, Brewer DB, Hardwick J, et al : The nephrotic syndrome. Q J Med 29: 598, 1972.

19) Trygstad CW, McCable E, Francyk WP, et al: Renal vein thrombosis and the nephrotic syndrome: a case report with protein selectivity studies. J Pediat. 76: 861, 1970.

20) Laurell CB : Quantitative estimation of protein by electrophroresis in agar gel containing antibodies. Ann Biochem 15: 45, 1966.

21) Hanson J, Berkman JI, Parkei JG, et al · A clinicopathologic study of chronic renal vein thrombosis in adults. Ann Int Med 49: 493, 1957.

22) Wegener GP, Crummy AB, Flaherty TT, et al: Renal vein thrombosis: a radiographic diagnosis. JAMA 209: 1661, 1060.

23) Rturgill B, Rawe CT: Renal vein thrombosis and nephrotic syndrome. Arch Int Med 120:708, 1967.

24) Kayfmann RH, De Graeff J, De La Riviere $\mathrm{GB}$, et al: Unilateral renal vein thrombosis and nephrotic syndrome. Report of a case with protein selectivity and antithrombin III clearance studies. Am J Med 60: 1048, 1976.

25) Jackson BT, Thomas JL, Daugherty GW : Post-thrombotic inferior vena caval obstruction. A review of 24 patients. Brit Med J 1: 13, 1970.

26) Fisher ER, Sharkey D, Pardo V, et al: Experimental renal vein constriction. Lab Invest 18:689, 1968.

27) Kanfer A, Kleinfecht D, Broyer M, et al : Coagulation studies in 45 cases of nephrotic syndrome without uremia. Thromb Diath Haemorrh 24 : 562, 1971.

28) Thomson G, Forbes CD, Prentice GRM : Changes in blood coagulation and fibrinolysis in nephrotic syndrome. Q J Med 43: 399, 1974.

29) Penick GD: Blood state that predispose to thrombosis. Thrombosis (Sherry S, Brinkhous KM, Genton E eds). National Academy of Science, Washington, D.C. p. 553, 1969.

30) Egeberg O: Inherited antithrombin deficiency causing thrombophilia. Thromb Diath Haemorrh 13: 516, 1965.

31) Alousi MA, Post RS, Heymann W, et al: Immunohistochemical and electronmicroscopic studies of experimental autoimmune nephrosis in rats: comparison with human renal biopsies. Feb Proc 26: 743, 1967. 
32) Glassock RJ, Edgington TS, Watson JI, et al: Autologous immune complex nephritis induced with renal tubular antigens: II the pathogenetic mechanism. J Exp Med 127:
573, 1968.

33) Harris JD, Ehrenfels WK, Wylie EJ: Experimental renal vein occulsions. Surg Gynec Obster 126 : 555, 1968. 